\title{
Research Paper Input utilization pattern in major maize hybrids in Haveri district of Karnataka: An economic analysis
}

See end of the paper for authors' affiliations

Correspondence to : SHILPA P. CHOWTI Department of Agricultural Economics, University of Agricultural Sciences, DHARWAD (KARNATAKA) INDIA Email: agrichoutishilpa@ gmail.com

Paper History:

Received : 06.11.2015;

Revised : 11.01.2016;

Accepted : 20.01.2016
AbSTRact : The present study attempts to analyze resource use pattern, cost and returns structure in major maize hybrids in Haveri district of Karnataka. The study was based on primary and secondary data. The required primary data was collected from sample farmers through personal interview method with the help of pre-tested and well structured schedule. A sample of 120 farmers from Haveri district was selected through multistage random sampling technique. The secondary data on area, production and productivity was collected from District Statistical Office for the period from 1998-99 to 2009-10. The annual growth rates for maize area and production were 3.41 per cent and 2.12 per cent and were significant at one and ten per cent level, respectively. The growth rate of maize yield was found to be negative $(-1.25 \%)$ but not significant. It was observed that, the farmers growing NK-6240 were found to use slightly more quantity of most of the inputs compared to the farmers growing $\mathrm{CP}-818$ and Sunny. Among the different operations the use of human labour was highest for harvesting, followed by sowing, hand weeding, threshing and spreading of FYM in all three hybrids. Per hectare cost of cultivation was slightly more in NK-6240 (Rs. 37,494) compared to CP-818 (Rs. 34,369) and Sunny (Rs. $36,120)$ with a respective benefit cost ratio of $1.88,1.79$ and 1.83 .

Key Words : Maize hybrids, Input use pattern, Cost of cultivation

How To Cite This PAPer : Chowti, Shilpa P. and Basavaraja, H. (2016). Input utilization pattern in major maize hybrids in Haveri district of Karnataka: An economic analysis. Internat. Res. J. Agric. Eco. \& Stat., 7 (1) :34-41. 